\title{
Physico-chemical and microbiological assay of the lake of the Eloy Chaves Botanical Park in Jundiaí-SP
}

\section{Débora Poleis Maciel, Anderson Luís Sabino, Renan Folchito de Souza, Ana Beatriz Carollo Rocha-Lima}

\begin{abstract}
The urban lake ecosystems are among the priority water bodies with regard to the need for proper management and conservation, because they have a direct influence on the conservation of local biodiversity and in aspects such as rainfall drainage. The lake of the Eloy Chaves Botanical Park in Jundiaí-SP is a lentic water body that has a fauna composed of fish, birds and reptiles, and receives water from rainwater galleries. This study evaluated the physicochemical parameters $(\mathrm{pH}$, orthophosphate, turbidity, nitrate, nitrite and dissolved oxygen) and microbiological parameters (thermotolerant coliforms) of the waters of the lake of the Eloy Chaves Botanical Park and the microbiological parameters of a rainwater gallery that flows into the lake. For this, we used the reagent kit Ecokit II® and Colipaper ${ }^{\circledR}$. The values obtained for the parameters orthophosphate and thermotolerant coliforms were in high concentration compared to the limit established for waters intended to protect aquatic communities (Class 2 of CONAMA Resolution 357/2005). In addition, the microbiological evaluation of rainwater gallery that flows into the lake showed high count of coliforms $(57.600 \mathrm{CFU} / 100 \mathrm{ml})$. Thus, despite the presence of flora and fauna on site, there is evidence of contamination caused by discharges of urban effluents into the rainwater gallery that flows into the lake, which may be affecting the water quality of this important urban ecosystem.
\end{abstract}

\section{Key words:}

Environmental Analysis, Water Resources, Coliforms.

\section{Introduction}

The urban lake ecosystems are among the priority water bodies with regard to the need for proper management and conservation, because they have a direct influence on the conservation of local biodiversity and in aspects such as rainfall drainage ${ }^{1}$. The lake of the Eloy Chaves Botanical Park in Jundiaí-SP is a lentic water body that has a fauna composed of fish, birds and reptiles, and receives water from rainwater galleries. This study evaluated the physico-chemical parameters $(\mathrm{pH}$, orthophosphate, turbidity, nitrate, nitrite and dissolved oxygen) and microbiological parameters (thermotolerant coliforms) of the waters of the lake of the Eloy Chaves Botanical Park and the microbiological parameters of a rainwater gallery that flows into the lake.

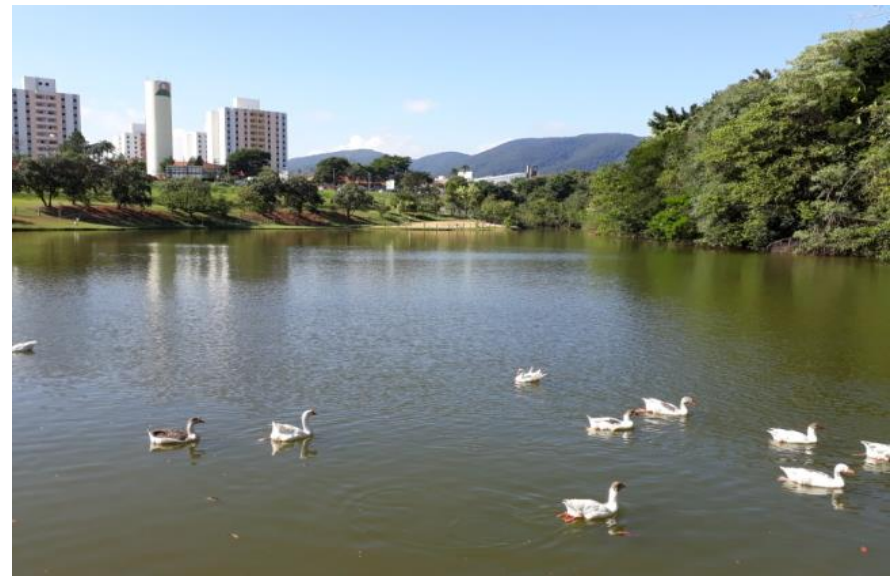

Image 1. Lake of the Eloy Chaves Botanical Park in Jundiaí-SP. Source: Souza, R. F. (2018)

\section{Results and Discussion}

We used the reagent kit Ecokit $I \AA$ and Colipaper®. The values obtained for the parameters orthophosphate and thermotolerant coliforms were in high concentration compared to the limit established for waters intended to protect aquatic communities (Class 2 of CONAMA Resolution 357/2005). In addition, the microbiological evaluation of rainwater gallery that flows into the lake showed high count of coliforms.

Chart 1. Main physico-chemical and microbiological results.

\begin{tabular}{|c|c|c|}
\hline Parameters & $\begin{array}{c}\text { CONAMA Resolution } \\
\mathbf{3 5 7 / 2 0 0 5} \text { (Class 2) }\end{array}$ & $\begin{array}{c}\text { Values } \\
\text { obtained }\end{array}$ \\
\hline Orthophosphate & $0,030 \mathrm{mg} / \mathrm{L}$ & $0,75 \mathrm{mg} / \mathrm{L}$ \\
\hline $\begin{array}{c}\text { Thermotolerant } \\
\text { coliforms (lake) }\end{array}$ & $1.000 \mathrm{CFU} / 100 \mathrm{ml}$ & $\begin{array}{c}7.200 \\
\mathrm{CFU} / 100 \mathrm{ml}\end{array}$ \\
\hline $\begin{array}{c}\text { Thermotolerant } \\
\text { coliforms } \\
\text { (rainwater gallery) }\end{array}$ & -- & $\begin{array}{c}57.600 \\
\text { CFU/100ml }\end{array}$ \\
\hline
\end{tabular}

According to related studies, this is an evidence of contamination caused by discharges of urban effluents ${ }^{2,3}$.

\section{Conclusions}

Thus, despite the presence of flora and fauna on site, there is evidence of contamination caused by discharges of urban effluents into the rainwater gallery that flows into the lake, which may be affecting the water quality of this important urban ecosystem.

${ }^{1}$ Corrêa, L. M. C. e Melo, C. Avifauna associada a ambientes lacustres: influência da preservação do habitat como instrumento para a conservação de espécies. IX Encontro interno e XIII Seminário de iniciação científica 2009. ${ }^{2}$ Guidolini, J. F.; Abdala, V. L. e Do Carmo, D. A. Ortofosfato como parâmetro indicador de qualidade da água em diferentes pontos da bacia do rio Uberaba. III Seminário de Iniciação Científica e Inovação Tecnológica. 2010. ${ }^{3}$ Ratti, B. A.; Brustolin, C. F.; Siqueira, T. A. e Torquato, A. S. Pesquisa de coliformes totais e fecais em amostras de água coletadas no bairro zona sete, na cidade de Maringá-PR. Anais Eletrônico VII EPCC - Encontro Internacional de Produção Científica Cesumar. 2011. 